\title{
DETERMINAN KINERJA PEGAWAI DENGAN MOTIVASI SEBAGAI VARIABEL INTERVENING
}

\author{
Muhammad Syukron Ginanjar ${ }^{1)}$; Indarto ${ }^{2)}$; Djoko Santoso ${ }^{3)}$ \\ ecb.jateng@gmail.com ${ }^{1)}$; indarto@usm.ac.id ${ }^{2}$; djoko hw@usm.ac.id $^{3)}$ \\ Magister Manajemen, Universitas Semarang, Semarang, Indonesia
}

\section{Info Artikel \\ Sejarah Artikel: \\ Diterima :Juli 2019 \\ Disetujui : Agustus 2019 \\ Dipublikasikan: Agustus \\ 2019}

\section{Keywords:}

work load; teamwork,

work; motivation;

performance.

\begin{abstract}
Abstrak
Penelitian ini bertujuan untuk mengetahui hubungan antara beban kerja dan kerjasama tim terhadap kinerja Pegawai dengan motivasi kerja sebagai variabel intervening. Jumlah populasi sejumlah 175. Sampel penelitian ini menggunakan 158 responden yaitu dari Pegawai Negeri pada Polri di Bagsumda Polres Jajaran Polda Jateng. Alat analisis yang digunakan pada penelitian ini adalah SEM. Hasil penelitian menunjukkan bahwa variabel independen (beban kerja) mempengaruhi kinerja Pegawai. Motivasi kerja terbukti sebagai variabel mediasi antara beban kerja terhadap kinerja Pegawai.
\end{abstract}

DETERMINANT PERFORMANCE OFEMPLOYEES WITH MOTIVATION AS INTERVENING VARIABLES

\section{Abstract}

This study aims to determine the relationship between workload and teamwork on employee performance with work motivation as an intervening variable. The total population is 175 . The sample of this study used 158 respondents, namely from the Civil Servants at the National Police in Bagsumda, Central Java Regional Police. The analytical tool used in this study is SEM. The results showed that the independent variable (workload) affected the employee's performance. Work motivation is proven as a mediating variable between workload and employee performance.

\footnotetext{
Alamat korespondensi :

Jalan Pahlawan, 1 , Kota Semarang

E-mail: ecb.jateng@gmail.com
} 


\section{PENDAHULUAN}

Sumber Daya Manusia menjadi salah satu modal utama dalam membangun peradaban dan perkembangan suatu bangsa. Negara Kesatuan Republik Indonesia mempunyai berbagai macam karakter Sumber Daya Manusia yang terbagi dalam beraneka ragam suku, budaya dan bahasa daerah. Sumber Daya Manusia yang terampil, terdidik, berintegritas, disiplin dan mampu bekerja dengan baik dalam tim ataupun perorangan akan mampu membangun peradaban dan perkembangan suatu bangsa.

Kepolisian Negara Republik Indonesia (POLRI) adalah hal - ihwal yang berkaitan dengan fungsi dan lembaga polisi sesuai dengan peraturan perundang undangan. Kepolisian Negara Republik Indonesia (POLRI) bertujuan untuk mewujudkan keamanan dalam negeri yang meliputi terpeliharanya keamanan dan ketertiban masyarakat, tertib dan tegaknya hukum, terselenggaranya perlindungan, pengayoman, dan pelayanan kepada masyarakat, serta terbinanya ketentraman masyarakat dengan menjunjung tinggi hak asasi manusia. (Undang - undang RI nomor 2 Tahun 2002 tentang Polri)

Polda Jawa Tengah yang beralamat di jalan Pahlawan 1 Semarang, merupakan salah satu instansi pemerintah di bawah Mabes Polri yang bertugas memelihara keamanan dan ketertiban masyarat, menegakkan hukum dan memberikan perlindungan, pengayoman dan pelayanan kepada masyarakat yang berada di Provinsi Jawa Tengah. Biro Sumber Daya Manusia Polda Jawa Tengah merupakan salah satu satuan kerja yang berada di bawah Polda Jawa Tengah. Kepolisian Resor (Polres) merupakan salah satu satuan kerja yang bertugas pada tingkat kewilayahan yang terbagi dalam 35 Kepolisian Resor (Polres). Bagian Sumber Daya (Bagsumda) merupakan salah satu satuan kerja yang berada di bawah Kepolisian Resor (Polres) yang mempunyai tugas salah satu nya adalah untuk melaksanaan pembinaan administrasi pegawai negeri pada Polri.

Sistem Informasi Personel Polri (SIPP) adalah sistem berbasis komputer yang dapat menerima, mengirim, menyimpan, mengolah dan menyajikan data dan informasi tentang Pegawai Negeri pada Polri secara online maupun manual yang akurat, berkualitas dan tepat waktu sebagai upaya mendukung penyelenggaraan pembinaan Sumber Daya Manusia Polri. Aplikasi adalah suatu subsistem perangkat lunak komputer yang memanfaatkan kemampuan komputer langsung untuk melakukan suatu tugas yang diinginkan pengguna (Peraturan Kepala Kepolisian Negara Republik Indonesia nomor 5 Tahun 2015). Validasi data pada aplikasi SIPP adalah proses pengumpulan, pengolahan dan verifikasi data pribadi Pegawai Negeri pada Polri yang dimasukkan pada aplikasi SIPP.

Bagsumda Polres jajaran Polda Jawa Tengah mempunyai tugas yang sangat penting dalam proses validasi data pada aplikasi SIPP yaitu melaksanakan verifikasi data yang sudah masuk pada aplikasi SIPP. Bagsumda membentuk tim yang bekerja dan bertugas untuk melaksanakan verifikasi data tersebut. Biro Sumber Daya Manusia Polda Jawa Tengah selaku satuan kerja di atas Bagsumda Polres memberikan target capaian penyelesaian proses validasi data pada aplikasi SIPP, target capaian tersebut sejumlah 100\% dari bulan Agustus hingga Desember Tahun 2018.

Menurut Haryanto (2014) beban kerja merupakan jumlah kegiatan yang harus diselesaikan oleh seseorang ataupun sekelompok orang selama periode waktu tertentu dalam keadaan normal. Kerjasama tim menjadi salah satu faktor keberhasilan suatu organisasi. melalui kerja sama, suatu pekerjaan akan terasa ringan tentu nya dengan pembagian beban kerja yang proporsional agar hasil akhir dari suatu pekerjaan dapat 
tercapai secara optimal. Menurut Roucek dan Warren (Busro. 2016) kerjasama tim berarti bekerja bersama - sama untuk mencapai tujuan bersama dan bukan berarti bersama - sama bekerja. Motivasi kerja menjadi salah satu faktor yang sangat penting dalam pencapaian keberhasilan tujuan organisasi. Robbins dan Jugde (2008) mendefinisikan motivasi sebagai proses yang menjelaskan intensitas, arah dan ketekunan seorang individu untuk mencapai tujuannya. Kinerja didefinisikan sebagai kemampuan kerja di dalam terminologi kualitas dan kuantitas (Khan et.al., 2010). pendapat tersebut dapat dipahami bahwa kinerja merupakan prestasi kerja (perfomance) baik bersifat kuantitas maupun kualitas yang dicapai oleh seseorang selama periode tertentu.

Tujuan dari penelitian ini yaitu Menganalisis pengaruh beban kerja terhadap Kinerja Pegawai Negeri pada Polri di Bagsumda Polres jajaran Polda Jawa Tengah, Menganalisis pengaruh kerjasama tim terhadap Kinerja Pegawai Negeri pada Polri di Bagsumda Polres jajaran Polda Jawa Tengah, Menganalisis pengaruh motivasi kerja terhadap Kinerja Pegawai Negeri pada Polri di Bagsumda Polres jajaran Polda Jawa Tengah, Menganalisis pengaruh beban kerja terhadap motivasi kerja Pegawai Negeri pada Polri di Bagsumda Polres jajaran Polda Jawa Tengah dan Menganalisis pengaruh kerjasama tim terhadap motivasi kerja Pegawai Negeri pada Polri di Bagsumda Polres jajaran Polda Jawa Tengah.

\section{TELAAH PUSTAKA}

Haryanto (2014) beban kerja merupakan jumlah kegiatan yang harus diselesaikan oleh seseorang ataupun sekelompok orang selama periode waktu tertentu dalam keadaan normal. Menurut Permendagri No. 12/2008, beban kerja adalah besaran pekerjaan yang harus dipikul oleh suatu jabatan atau unit organisasi dan merupakan hasil kali antara volume kerja dan norma waktu. Penelitian yang dilakukan oleh Anita (2013) menunjukkan hasil bahwa ada pengaruh negatif dan signifikan antara beban kerja terhadap motivasi kerja. Penelitian lain yang dilakukan oleh Prahastari (2014) menunjukkan hasil bahwa ada pengaruh positif dan signifikan antara beban kerja terhadap motivasi kerja. Berdasarkan uraian tersebut dapat dirumuskan hipotesis berikut:

H1 : Beban kerja berpengaruh terhadap motivasi kerja.

Menurut Roucek dan Warren (Busro. 2016) kerjasama tim berarti bekerja bersama - sama untuk mencapai tujuan bersama dan bukan berarti bersama - sama bekerja. Penelitian yang dilakukan oleh Pangadiyono (2018) menunjukkan hasil bahwa kerjasama tim berpengaruh positif dan signifikan terhadap motivasi.

Berdasarkan uraian tersebut dapat dirumuskan hipotesis berikut:

$\mathrm{H} 2$ : Kerjasama tim berpengaruh terhadap motivasi.

Robbins dan Jugde (2008) mendefinisikan motivasi sebagai proses yang menjelaskan intensitas, arah dan ketekunan seorang individu untuk mencapai tujuannya. Robbins (2008) dalam pandangan yang lain mengemukakan bahwa pengertian motivasi kerja meliputi upaya (effort), tujuan organisasi (organizational goals), dan kebutuhan (needs). Unsur "upaya" merupakan intensitas. Upaya yang diarahkan tersebut haruslah konsisten dengan tujuan organisasi, adapun kebutuhan adalah keadaan internal yang menyebabkan hasil - hasil tertentu tampak menarik. Penelitian yang dilakukan oleh 
Taroreh (2014) menunjukkan hasil bahwa motivasi kerja berpengaruh signifikan positif terhadap kinerja. Penelitian yang dilakukan oleh Waisnawini (2014) menyimpulkan bahwa motivasi kerja berpengaruh positif dan signifikan terhadap kinerja karyawan. Berdasarkan uraian tersebut dapat dirumuskan hipotesis berikut:

H5 : Motivasi berpengaruh positif signifikan terhadap kinerja.

Beban kerja menurut Suwatno (2003) adalah sejumlah kegiatan yang harus diselesaikan oleh suatu unit organisasi atau pemegang jabatan secara sistematis dengan menggunakan teknik analisis jabatan, teknik analisa beban kerja atau teknik manajemen lainnya dalam jangka waktu tertentu untuk mendapatkan informasi tentang efisiensi dan efektifitas kerja suatu unit organisasi. Beban kerja setiap pegawai berbeda - beda tergantung fungsi dimana pegawai tersebut berada. Hasil analisis Gozali (2016) menunjukkan bahwa beban kerja berpengaruh negatif dan signifikan terhadap kinerja karyawan. Semakin tinggi beban kerja semakin rendah kinerja yang dihasilkan, demikian juga sebaliknya semakin rendah beban kerja maka kinerja pegawai semakin tinggi. Penelitian Muhammad (2016) menyimpulkan beban kerja berpengaruh signifikan terhadap kinerja karyawan. Berdasarkan uraian tersebut dapat dirumuskan hipotesis berikut:

H3 : Beban kerja berpengaruh negatif signifikan terhadap kinerja.

Menurut Roucek dan Warren (Busro. 2016) kerjasama tim berarti bekerja bersama - sama untuk mencapai tujuan bersama dan bukan berarti bersama - sama bekerja. Kerjasama tim merupakan sebuah bentuk proses sosial yang didalamnya terdapat berbagai macam jenis aktifitas yang dimaksudkan untuk mencapai tujuan bersama dengan saling bantu - membantu dan saling mengerti aktifitas masing - masing anggota. Dalam kerjasama tim yang menjadi pokok utama adalah bekerja secara bersama - sama bukan yang bekerja 1 atau 2 orang kemudian anggota yang lainnya hanya terima hasil akhir, tentunya proses kerjasama tidak semudah itu. Kerjasama tim membutuhkan kekompakan, komunikasi dan komitmen yang jelas antar anggota tim. Hasil analisis yang dilakukan oleh Rahmawati (2015) menunjukkan hasil bahwa Kerjasama tim berpengaruh positif terhadap kinerja lembaga KKH PRG dalam keamanan hayati Indonesia. Kerjasama tim merupakan solusi yang terbaik untuk mencapai kesuksesan fungsi dan tugas kinerja KKH PRG. Penelitian yang dilakukan oleh Taroreh (2014) dengan hasil Kerjasama tim berpengaruh signifikan positif terhadap kinerja Suster, juga membuktikan hal yang sama. Berdasarkan uraian tersebut dapat dirumuskan hipotesis berikut :

H4 : Kerjasama tim berpengaruh signifikan terhadap kinerja.

\section{METODE}

Jenis penelitian yang dilakukan adalah penelitian kausalitas. Penelitian kausalitas adalah penelitian yang menunjukkan sebab akibat antar 2 konstruk dan bersifat terstruktur (istijanto, 2008). Ragam data yang diperoleh dari sumbernya, contohnya pendapat pelanggan yang ditanya atau obyek yang diamati cenderung berpola lebih terstruktur sehingga hasil yang diperoleh mudah untuk dibaca oleh peneliti. Jenis data yang dikumpulkan merupakan data primer. Data primer tersebut diperoleh dengan cara menyebar kuesioner kepada Pegawai Negeri pada Polri di Bagsumda Polres jajaran Polda jateng. Jumlah Polres yang ada di jajaran Polda Jateng yaitu 35 Polres. Dengan menggunakan kuesioner peneliti meminta responden untuk 
mengisi secara mandiri pertanyaan - pertanyaan yang dibuat oleh peneliti yang termuat dalam daftar pertanyaan yang diberikan kepada para responden. Cara alternatif yang dilakukan untuk mendapatkan sumber data yang diperlukan adalah dengan cara survey lapangan / mengantar kuesioner secara langsung kepada responden.

Data primer dalam penelitian kuantitatif terbagi menjadi 3 macam yaitu survei, observasi dan eksperimen (Istijanto, 2008). Dalam penelitian yang dilakukan oleh peneliti ini fokus pada tujuan untuk mendapatkan hasil berupa data primer dengan melakukan survei langsung ke lapangan dengan menyebarkan kuesioner. Survei diharapkan mencakup seluruh pegawai negeri pada Polri di Bagsumda Polres jajaran Polda Jateng sehingga hasil survei yang dilakukan dipandang dapat mewakili seluruh populasi atau sebagian besar pegawai negeri pada Polri di Bagsumda Polres jajaran Polda Jateng.

Dalam pelaksanaan survei penelitian ini, penyebaran kuesioner secara terstruktur yang berarti semua pertanyaan yang diajukan kepada setiap responden merupakan pertanyaan standar (Pertanyaan yang diajukan sama dan tertulis secara rinci).

Metode pengumpulan data yang dilakukan dalam penelitian ini yaitu dengan membagikan angket kuesioner yang sudah disiapkan kepada para responden secara langsung sehingga hasil pengisiannya akan lebih akurat dan jelas. Daftar pertanyaan yang ada dalam kuesioner tersebut berisi gambaran umum, perhatian dan pendapat responden berkaitan dengan pengaruh beban kerja dan kerjasama tim terhadap kinerja pegawai negeri pada Polri dengan motivasi kerja sebagai variabel intervining.

\section{HASIL DAN PEMBAHASAN}

Dalam langkah ini, peneliti mendeskripsikan menggunakan gambar sebuah diagram alur yang dapat mempermudah dalam melihat hubungan - hubungan kausalitas yang akan diuji dalam penelitian ini. Adapun diagram alur dari beberapa variabel dalam penelitian ini disajikan dalam gambar 1 berikut ini.

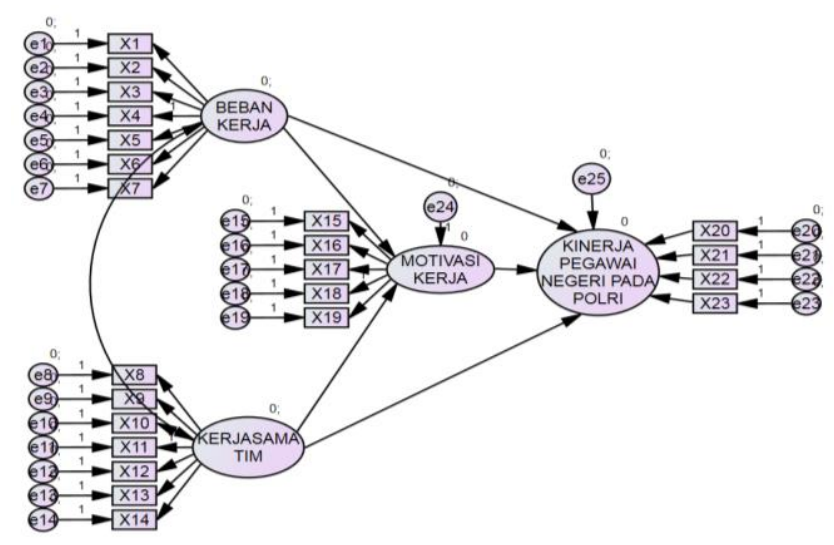

Gambar 1. Menunjukkan adanya konstruk - konstruk eksogen dan endogen. 
Pengujian menggunakan fit indeks bertujuan untuk mengukut "kebenaran" model. Beberapa fit indeks dan cut off value yang digunakan dalam menguji apakah model tersebut dapat diterima atau ditolak seperti terdapat pada Tabel 1 (Ferdinand, 2005)

Tabel 1

Goodness Of Fit Test Full Model

\begin{tabular}{|c|c|}
\hline Goodness of Fit Index & Cut off Value \\
\hline Chi square & Diharapkan kecil \\
\hline Significant Probability & $\geq 0,05$ \\
\hline CMIN/DF & $\leq 2,00$ \\
\hline GFI & $\geq 0,90$ \\
\hline AGFI & $\geq 0,90$ \\
\hline TLI & $\geq 0,95$ \\
\hline CFI & $\geq 0,95$ \\
\hline RMSEA & $\leq 0.08$ \\
\hline
\end{tabular}

Sumber : Data Primer yang diolah, 2019

Analisis hasil pengolahan data pada tahap full model SEM dilakukan dengan melakukan uji kesesuaian dan uji statistik. Hasil pengolahan data untuk analisis full model SEM ditampilkan pada Gambar 2.

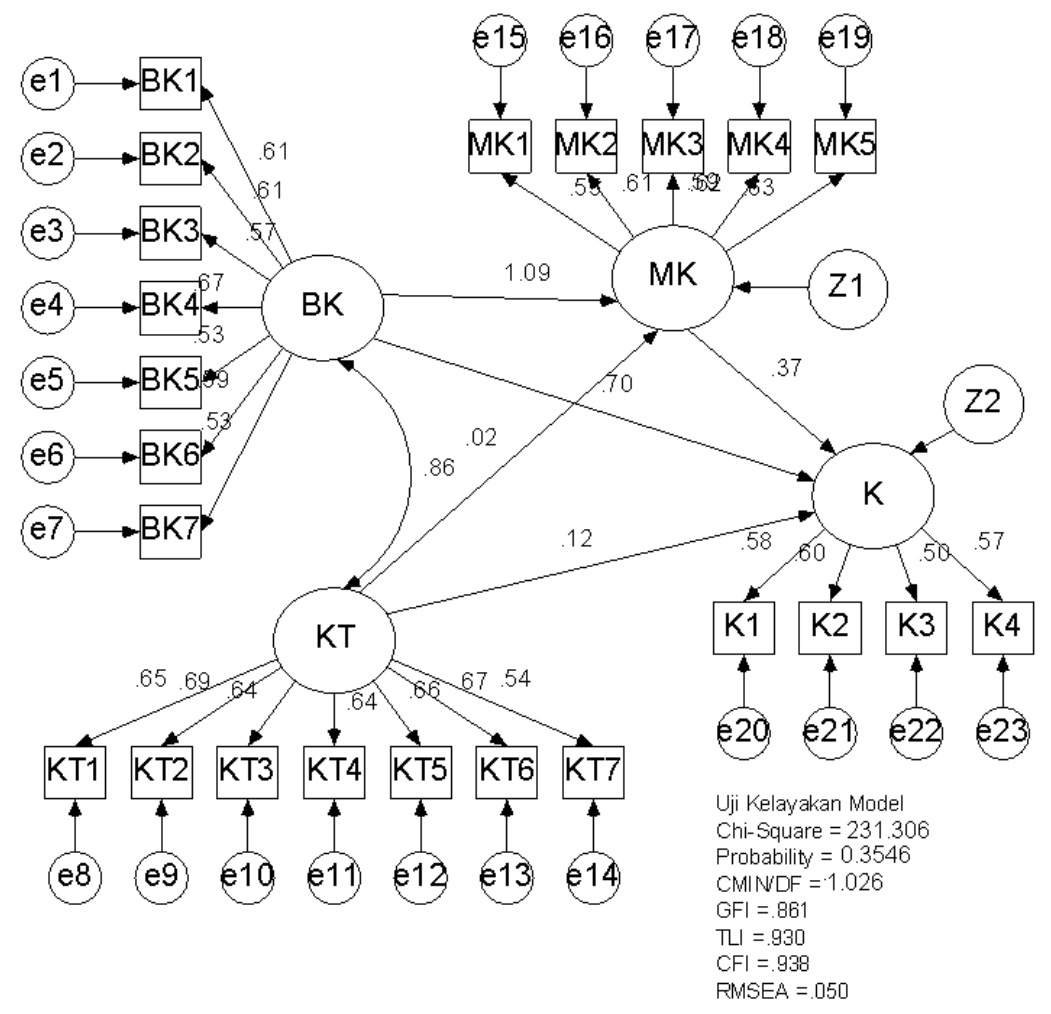

Gambar 2. Hasil Uji Full Model-Structural Equation Model (SEM) Tahap 1 
Hasil uji kelayakan model penelitian, secara keseluruhan semua kriteria Goodness of Fit Structural Equation Model (SEM) yang diterima sebagaimana terlihat pada tabel berikut ini.

Tabel 2

Goodness of Fit Structural Equation Model (SEM)

\begin{tabular}{|l|c|c|c|}
\hline Goodness of Fit Indeks & Cut-off value & Hasil analisis & Evaluasi model \\
\hline Chi square & $\leq 259,9144$ & 231.30 & Baik \\
\hline Probability & $\geq 0,05$ & 0,354 & Baik \\
\hline RMSEA & $\leq 0,08$ & 0,050 & Baik \\
\hline GFI & $\geq 0,90$ & 0,861 & Kurang Baik \\
\hline TLI & $\geq 0,90$ & 0,930 & Baik \\
\hline CFI & $\geq 0,90$ & 0,938 & Baik \\
\hline CMIN/DF & $\leq 2,00$ & 1,026 & Baik \\
\hline
\end{tabular}

Sumber : Data primer yang diolah, 2019

Hasil analisis SEM sebagai langkah pengujian hipotesis sebagai berikut:

Tabel 3

Output Regression Weights

\begin{tabular}{|c|c|c|c|c|c|c|c|}
\hline & & & Estimate & S.E. & C.R. & P & Label \\
\hline Motivasi Kerja & $<---$ & Kerjasama Tim & .024 & .191 & .126 & .900 & \\
\hline Motivasi Kerja & $<---$ & Beban Kerja & -1.240 & .303 & -4.087 & $* * *$ & \\
\hline Kinerja & $<---$ & Motivasi Kerja & .364 & .145 & 2.508 & .012 & \\
\hline Kinerja & $<---$ & Beban Kerja & -.796 & .197 & -4.042 & $* * *$ & \\
\hline Kinerja & $<---$ & Kerjasama Tim & .118 & .146 & .809 & .418 & \\
\hline
\end{tabular}

Sumber : data primer yang diolah, 2019

Berdasarkan hasil pengujian hipotesis yang disajikan pada Tabel 4.14, dibuat ringkasan seperti tersaji pada Tabel 4.15

Tabel 4.15

\section{Ringkasan Hasil Pengujian Hipotesis}

\begin{tabular}{|c|c|c|c|}
\hline & & & Keterangan \\
\hline Motivasi Kerja & $<---$ & Kerjasama Tim & Ditolak \\
\hline Motivasi Kerja & $<---$ & Beban Kerja & Diterima \\
\hline Kinerja & $<---$ & Motivasi Kerja & Diterima \\
\hline Kinerja & $<---$ & Beban Kerja & Diterima \\
\hline Kinerja & $<---$ & Kerjasama Tim & Ditolak \\
\hline
\end{tabular}

Sumber : data primer diolah, 2019 


\section{PENUTUP}

Berdasarkan hasil dan intepretasi pada bab sebelumnya, maka dapat ditarik kesimpulan penelitian yaitu Beban kerja berpengaruh negatif terhadap Motivasi Kerja. Semakin tinggi beban kerja yang diberikan maka semakin kecil Motivasi Kerja dan sebaliknya jika beban kerja yang diberikan kecil maka Motivasi Kerja semakin besar, Kerjasama tim tidak berpengaruh terhadap Motivasi Kerja. Semakin tinggi maupun rendah kerjasama tim tidak akan mampu meningkatkan atau menurunkan motivasi kerja, Motivasi kerja berpengaruh positif terhadap kinerja. Semakin tinggi Motivasi kerja maka semakin baik kinerjanya dan sebaliknya jika motivasi kerja rendah, maka semakin kurang kinerjanya, Beban kerja berpengaruh negatif terhadap kinerja. Semakin tinggi beban kerja yang diberikan maka semakin kurang kinerja dan sebaliknya jika beban kerja yang diberikan kecil maka kinerja semakin meningkat dan Kerjasama Tim tidak berpengaruh terhadap kinerja. Semakin tinggi maupun rendah kerjasama tim tidak akan mampu meningkatkan atau menurunkan kinerja.

Berdasarkan hasil dan intepretasi pada bab sebelumnya, maka dapat diambil implikasi manajerial penelitian. Variabel beban kerja terhadap kinerja membuktikan adanya pengaruh. Maka dari itu, manajemen diharapkan dalam mencapai tujuan organisasi hendaknya memberikan beban kerja sesuai dengan porsi tanggung jawab sebagai masing-masing agar kinerja tim dan organisasi secara keseluruhan dapat menunjukkan kinerja pelayanan yang sesuai dengan harapan. Selain itu keadilan pembagian beban kerja harus berimbang sehingga tidak menimbulkan kesenjangan sosial dan kinerja tetap dapat terjaga. Kerjasama tim terbukti tidak mempengaruhi kinerja hal ini menunjukkan bahwa kinerja tim pada pelaksanaan validasi data pada aplikasi SIPP khususnya di Bagsumda Polres jajaran Polda Jateng belum optimal. Alangkah baiknya perlu diberikan pelatihan kerjasama tim lebih baik agar lebih efektif dalam memberikan performa kinerja tim dalam rangka pencapaian tujuan tugas pelaksanaan validasi data pada aplikasi SIPP. Selain itu pembinaan kerjasama tim lebih ditekankan agar dapat mempengaruhi kinerja Pegawai di masa depan. Beban kerja mempengaruhi Motivasi kerja. Manajemen dalam organisasi hendaknya melihat apakah beban kerja yang tinggi dapat meningkatkan Motivasi kerja atau malah sebaliknya. Setiap pegawai mempunyai tingkat Motivasi yang berbeda namun memiliki tanggung jawab yang sama. Meskipun demikian, evaluasi kinerja sangat diprioritaskan agar yang potensial yang mampu mengelola Motivasi kerja dapat memajukan organisasi dengan bertanggung jawab pada beban kerja yang diembannya. Kerjasama tim tidak dapat memotivasi pegawai dalam melaksanakan tugas organisasi kepolisian hendaknya evaluasi standar operasional prosedur dalam pembentukan tim kerja dalam validasi data SIPP serta mengevaluasi bentuk kerjasama yang dilakukan dalam menyelesaikan tugas sehingga dapat ditemukan dimensi kerjasama tim yang tidak efektif dalam memotivasi pegawai. Motivasi kerja berpengaruh terhadap kinerja manajemen diharapkan dapat memberikan kompensasi ataupun pengakuan pada tiap-tiap individu namun masih memungkinkan dan rasional agar dapat memicu kinerja lebih baik. Hal ini dapat meningkatkan prestasi dengan adanya peningkatan kompensasi sebagaimana prestasi merupakan hasil pengukuran dari kinerja.

Berdasarkan simpulan penelitian di atas, penelitian ini memiliki beberapa keterbatasan antara lain sebagai berikut Sebaran data untuk setiap observed variable pada univariate outlier menunjukkan masih terindikasi outlier. Hal ini ditunjukkan 
dengan nilai minimum maksimum $Z$ dari data penelitian yang nilainya ada yang masih berada pada rentang lebih dari \pm 3.00 Konstruk yang digunakan masih terbatas yaitu hanya 2 variabel independen saja dengan 1 variabel mediasi dan salah satu variabel independen berperan sebagai variabel mediasi.

\section{DAFTAR PUSTAKA}

Alfian, Ferri, 2017. Pengaruh keterlibatan kerja, beban kerja dan konflik peran terhadap kepuasan kerja serta dampaknya pada kinerja pegawai pada dinas pendidikan Aceh. Universitas Syiah Kuala.

Anita, Julia. 2013. Pengaruh penempatan dan beban kerja terhadap motivasi kerja dan dampaknya pada prestasi kerja pegawai dinas tenaga kerja dan mobilitas penduduk Aceh.Universitas Syiah Kuala.

Bowo dan Andy. 2007. Pengertian kerjasama. [online], (http://lompoulu.blogspot.com/2013/06

Busro, Muhammad. 2016. Teori - Teori Manajemen Sumber Daya Manusia. Jakarta: Kencana.

Ellyzar, Nova, 2017. Pengaruh mutasi kerja, beban kerja, dan konflik interpersonal terhadap stress kerja serta dampaknya pada kinerja pegawai BPKP perwakilan Provinsi Aceh. Universitas Syiah Kuala.

Ferdinand. 2006. Metode Penelitian Manajemen. Semarang ; Bp Undip.

Ferdinand. 2015. Metode Penelitian Manajemen. Semarang; Bp Undip.

Gozali, Nurhamidah, 2016. Pengaruh beban kerja dan karakteristik individu terhadap kepuasan kerja serta dampaknya terhadap kinerja pegawai badan pusat statistik (Studi kasus pada BPS Kabupaten Deli Serdang dan kabupaten Serdang Bedagai. Universitas Terbuka.

Griffin, Ricky. 2000. Management. Edisi 2. Penerjemah Gina Gania. Jakarta: Erlangga.

Haryanto, 2014. Sistem Manajemen Basis Data: Pemodelan, Perancangan, dan Terapannya, Informatika, Bandung.

Hastutiningsih, Artha Tri, 2018. Pengaruh beban kerja dan lingkungan kerja terhadap kinerja karyawan dimediasi stres kerja (studi pada PT. MSV Pictures Yogyakarta). Universitas Islam Indonesia.

Hatta, Muhammad, 2017. Pengaruh gaya kepemimpinan, kerjasama tim dan kompensasi terhadap kepuasan kerja serta dampaknya pada kinerja karyawan PT. PLN (persero) wilayah Aceh. Universitas Syiah Kuala.

http://www.studygs.net/melayumanado/cooplearn.html. Diakses 8 Januari 2019

Istijanto, 2008. Riset Sumber Daya Manusia. PT. Gramedia Pustaka Utama : jakarta.

Kasmarani, M. K., 2012. Pengaruh Beban Kerja Fisik dan Mental terhadap Stres kerja pada perawat di instansi gawat darurat (IGD) RSUD Cianjur. Jurnal Kesehatan Masyarakat. Vol 1, No. 2, PP. 767-776.

Keban, Jeremias T. 2008. Enam DImensi Strategis Administrasi Publik:Konsep, Teori, dan Isu. Yogyakarta: Penerbit Gava Media.

Khan, Muhammad Riaz et.al.2010. "The Impacs of organizational Commitment on Employee Job Performance."European Journal of Social Science, Vol.15 Number 3,pp.292.298.

Lakoy, Amanda Carolina, 2015. Pengaruh komunikasi, kerjasama kelompok, dan kreativitas terhadap kinerja karyawan pada hotel aryaduta Manado. Universitas Sam Ratulangi Manado.

Luthans, Fred.2002. Organizational Behavior. 7th Ed. New York:McGraw-Hill. 
Mangkunegara, Anwar Prabu. 2008. Perilaku Organisasi dan Budaya Organisasi. Bandung: PT. Refika Aditama.

Manzoor, Q.A. 2012. "Impact of Employees Motivation on Organizational Effectiveness". Business Management and Strategy, Dep. Of Management Sciences. The Islamia University of Bahawalpur, Bahawalpur Pakistan. ISSN 2157-6068, Vol. 3, No. 1,pp.

Martoyo, Susilo, 2007. Manajemen Sumber Daya Manusia, BPFE, Yogyakarta.

Moon, M. Jae. 2000. "Organizational Commitment Revisited in New Public Management (Motivation, Organizational, Culture, Sector and Manajerial Level." Public Performance \& Management Review, Vol. 24, No. 2, Desember 200, p. 177-194.

Pabundu, Tika. 2006. Budaya organisasi dan peningkatan kinerja perusahaan. Jakarta:Bumi Aksara.

Pangadiyono. 2018. Analisis kerjasama tim dan budaya organisasi terhadap kinerja unit kegiatan mahasiswa dengan variabel intervening motivasi. Universitas Sarjanawiyata Tamansiswa.

Peraturan Menteri Dalam Negeri.2008. Peraturan Menteri Dalam Negeri No. 12 Tahun 2008 tentang Pedoman analisis beban kerja di lingkungan departemen dalam negeri dan pemerintah daerah. Mendagri. Jakarta.

Prahastari, Oktaviana Ayu. 2014. Pengaruh beban kerja dan komunikasi terhadap motivasi serta dampaknya pada kinerja karyawan Bank jateng cabang utama Semarang. Universitas Dian Nuswantoro.

Pulungan, Nurmardhiyah, 2017. Pengaruh beban kerja, kepuasan kerja dan komitmen organisasi terhadap kinerja pemeriksa BPK RI perwakilan Provinsi Lampung.Universitas lampung.

Purwaningsih, Ratna dan Sugiyanto, Arief. 2007. Analisis beban kerja mental DOsen Teknik Industri Undip dengan metode Subjective Workload Assessment Technique (SWAT). Universitas Diponegoro, Vol II, No 2, Mei 2007.

Rahmawati, Cynthia, 2015. Pengaruh kompetensi dan kerjasama tim terhadap kinerja lembaga komisi keamanan hayati produk rekayasa genetik (KKH PRG) dalam keamanan hayati Indonesia. Universitas Suryadarma.

Republik Indonesia.2002. Undang-Undang No. 2 Tahun 2002 tentang Kepolisian Negara Republik Indonesia, Sekretaris Negara. Jakarta.

Republik Indonesia.2015. Peraturan Kepala Kepolisian Negara Republik Indonesia No. 5 Tahun 2015 tentang Sistem Informasi Personel Kepolisian Negara Republik Indonesia, Kapolri. Jakarta.

Robbins SP dan Judge. 2008. Perilaku Organisasi Buku 2, Jakarta : Salemba Empat.

Sugiyono. 2008. Metode Penelitian Kuantitatif Kualitatif dan $R$ dan D, CV. Alfabeta, Bandung.

Suwatno. 2003. Azas - Azas Sumber Daya Manusia. Bandung:UPI Press.

Suwatno, H.2011. Manajemen SDM dalam Organisasi Publik dan Bisnis.Bandung : Alfabeta.

Tangkilisan, Hessel Nogi. 2005. Manajemen Publik. Jakarta: PT Gramedia Widiasarana Indonesia.

Taroreh, Imeldi Maria, 2014. Analisa pengaruh motivasi kerja, pelatihan, kepemimpinan, komunikasi dan kerjasama tim terhadap kinerja para suster dina ST. Yoseph di Indonesia. Universitas Sam Ratulangi.

William, C. 2002. Management. Cincinnati, Ohio:South-Western College Publishing. 